\title{
Characterization and nutritional value of precooked products of kiwicha grains (Amaranthus caudatus)
}

\author{
Verónica Elizabeth BURGOS ${ }^{1 *}$, Margarita ARMADA ${ }^{1}$
}

\begin{abstract}
Kiwicha has significant nutritional characteristics. It is commonly used as a puffed product, but there is little research on the lamination process. In this paper, the physical, functional properties, chemical composition and acceptability of the precooked kiwicha grains were studied. Puffed (PK) and laminated kiwicha (LK) were made. Puffed amaranth (CPA) was used as a commercial reference standard. The raw grain (RG) showed a higher bulk density $(0.85 \mathrm{~g} / \mathrm{ml})$ than in PK $(0.18 \mathrm{~g} / \mathrm{ml})$ and LK $(0.38 \mathrm{~g} / \mathrm{ml})$. Both products had a good expansion. The yellow index decreased in PK (50.92) and LK (45.87) respect to RG (65.64). The largest was CPA (58.54). In all the products, the precooking increased the index of absorption, solubility and swelling power. Also, they showed major pasting temperature, low peak viscosity and breakdown viscosity. In both formulated products, the content of total, soluble and insoluble dietary fibre decreased during the precooking process. The content of protein was optimal (between $14.57-14.59 \mathrm{~g} / 100 \mathrm{~g})$. PK had high acceptability (5.84), preference (84.48\%), purchase (38.79\%) and consumption (43.96\%) intention. The lowest was CPA. This work demonstrates that it's feasible to make precooked products with good quality characteristics, chemical composition and acceptability for the development of new products.
\end{abstract}

Keywords: kiwicha; precooked products; physical and functional properties; acceptability; chemical composition.

Practical Application: The research aims to develop precooked products with good quality characteristics, functional, nutritional value and sensory acceptability, for the development of new products for useful purposes. The use of a laminator and an aluminium pan adapted for the production of the puffed product are a novel idea. Therefore, these products will allow the revaluation of this Andean crop produced in the region and its importance to the regional economy.

\section{Introduction}

Amaranth is a pseudocereal which is believed to have originated in central and southern America (Gamel et al., 2006). The genus Amaranthus contains over 60 species and most of them are native to Latin America (Schoenlechner et al., 2008). However, only three species of amaranth are used for edible grain production: Amaranthus cruentus L., Amaranthus caudatus L., and Amaranthus hypochondriacus L. (López-Mejía et al., 2014; Milán-Carrillo et al., 2012). The most important Andean species is A. caudatus Linnaeus. In Quechua, the local language, it is called "kiwicha". It is cultivated in the Andes of Peru, Bolivia, Ecuador and Argentina (Repo-Carrasco-Valencia et al., 2009). Amaranth contains 13-19\% protein, 58-66\% starch (Bressani, 2003; Montoya-Rodríguez et al., 2015), 14-16\% total dietary fibre (Repo-Carrasco-Valencia et al., 2009). The lipid content shows wide variations, between $1.9 \%$ and $9.7 \%$, depending on the species and genotype. The content of fatty acids: palmitic (19\%), oleic (31.3\%) and linoleic (38\%) (Palombini et al., 2013). It is also important to highlight that the amaranth oil is a rich source of squalene (Gamel et al., 2007). The puffing operation of cereals consists of the sudden application of heat at atmospheric pressure so that the moisture is vaporized inside the grain reaching high internal pressures. At this stage, the external tissue is broken and the grain is expanded, forming the endosperm foam attached to the fragments of pericarp and embryo (Mariotti et al., 2006). The most important quality parameter of the popped product is the expansion volume obtained due to the characteristics of the raw grain (Chen \& Yeh, 2001), and the processing conditions (Chandrasekhar \& Chattopadhyay, 1990). The process variables are grain size, thickness of pericarp, temperature, pressure, water activity and the moisture (between $14 \%$ and 16\%) (Boischot et al., 2003; Chavez-Jauregui et al., 2000; Gökmen, 2004; Moraru \& Kokini, 2003; Shimoni et al., 2002). The lamination operation involves the application of heat at low pressure and mashing in thin flakes, enabling the following benefits: removing bacteria, inactivating anti-nutritional factors, changing the physical appearance of the food and increasing the volume and digestibility. The final product obtained by lamination is called flakes or chips, which has a moisture content of 8 to $10 \%$ (Bressani, 2006). The aim of this study was to evaluate the physical, functional properties, chemical composition and acceptability of precooked products made of kiwicha grains (Amaranthus caudatus).

\section{Materials and methods}

\subsection{Raw material}

We worked with kiwicha grain (Amaranthus caudatus), crop 2013, from the local town of Cachi in the province of Salta. Commercial puffed amaranth (CPA) was used as a reference standard. 


\subsection{Puffed operation}

The puffed operation was performed according to the methodology developed by Muyonga et al. (2014), with some modifications. An aluminium pan was used to make puffed corns. It was adapted for the production of the puffed product due to the small size of the grains of kiwicha. The pan consists of a lid with a propeller that allows the grains to be mixed, as they are popped. A gas cooker Tivoli 500 G.E. V/S 50CM (Argentina) was also used. After the puffed operation, the popped grains were passed through a 16 mesh (1.190 mm ASTM) to be selected for analysis. The process variables were: the initial moisture, $7.20 \%$; the expansion time, 30 seconds; the temperature $160{ }^{\circ} \mathrm{C} \pm 2{ }^{\circ} \mathrm{C}$ measured with the infrared thermometer $\mathrm{CEM}\left(-50^{\circ} \mathrm{C}-500^{\circ} \mathrm{C}\right)$. The product obtained was called puffed kiwicha (PK).

\subsection{Lamination operation}

The lamination operation requires a double drum roller. The sample is placed in the feed zone and then passes to the outer surface of the heated rollers, which rotates slowly on its horizontal axis. The accumulation of material remains on the rollers at approximately $80 \%$ of revolutions; during this time, the moisture evaporates, and leaves a solid material which is removed from the roll surface with a scraper (Gavrielidou et al., 2002). Prior to the lamination process, the kiwicha grains were moisturized to a mass/volume relation of 1:0.8. The process variables were: initial moisture content, $18 \%$; roller temperature, $100{ }^{\circ} \mathrm{C}$; residence time of 11 seconds to $5 \mathrm{rpm}$. The product obtained was called laminated kiwicha (LK).

\subsection{Bulk density (BD) and Expansion Index (EI)}

The BD measurement should be determined by measuring the material volume, which is compacted in a cylinder of $25 \mathrm{ml}$ and the results were calculated as g/ml (Mariotti et al., 2006). The EI was calculated between the volume of the raw grains and the same volume after being expanded, using the following Equation 1.

$\mathrm{EI}=\frac{\text { Volume raw grain }(\mathrm{ml})}{\text { Volume expanded grain }(\mathrm{ml})}$

\subsection{Determination of colour. Yellow Index (YI)}

Colour was determined with the Colour Tec PCM (Accuracy Microsensor Inc., Pittsford, USA), the Cole Parmer reflectance colorimeter equipped with light source D65 and an observation angle of $10^{\circ}$. The measurements were triplicated for each sample. CIELAB parameters $\left(\mathrm{L}^{*}, \mathrm{a}^{*}, \mathrm{~b}^{*}\right)$ were used and $\mathrm{L}^{*}$ measured on the scale from black (zero) to white (100), and the other two related to chromaticity: $a^{*}$ from green $\left(-a^{*}\right)$ to red $\left(+a^{*}\right)$ and $b^{\star}$ from blue $\left(-b^{\star}\right)$ to yellow $\left(+b^{\star}\right)$. The YI was determined by using the following Equation 2 (Rufian-Henares et al., 2006).

$$
\mathrm{YI}=\frac{142.86 \times \mathrm{b}^{*}}{\mathrm{~L}^{*}}
$$

\subsection{Functional properties}

Water absorption index (WAI) and water solubility index (WSI) were determined by the method of Anderson et al. (1969). The swelling power (SP) was determined by a modification of the original method of Schoch (1964), by Sathe \& Salunkhe (1981).

\subsection{Pasting properties}

Pasting properties of the samples were determined using a Viscoamylograph (Brabender OHG, Duisburg, Germany). The test preparation consisted in suspending the milled samples with a particle size of 40 mesh ( $0.400 \mathrm{~mm}$ - ASTM) in distilled water to $7 \% \mathrm{w} / \mathrm{v}$, then brought to a final volume of $530 \mathrm{cc}$. with the following heating-cooling cycle: heating at a rate of $1.5^{\circ} \mathrm{C} / \mathrm{min}$; starting temperature $20^{\circ} \mathrm{C}$ up to $90^{\circ} \mathrm{C}$; maintained at $90^{\circ} \mathrm{C}$ for $20 \mathrm{~min}$; cooled from $90^{\circ} \mathrm{C}$ to $50{ }^{\circ} \mathrm{C}$ for $1.5 / \mathrm{min}$; maintained at $50^{\circ} \mathrm{C}$ for $20 \mathrm{~min}$.. The amylographic parameters were determined: pasting temperature, viscosity peak, viscosity at $90^{\circ} \mathrm{C}$, viscosity at $90{ }^{\circ} \mathrm{C}$ for $20 \mathrm{~min}$, viscosity at $50{ }^{\circ} \mathrm{C}$, viscosity at $50{ }^{\circ} \mathrm{C}$ for $20 \mathrm{~min}$, breakdown viscosity (difference between the viscosity peak and viscosity at $90^{\circ} \mathrm{C}$ for $20 \mathrm{~min}$ ) and setback viscosity (difference between the viscosity at $50{ }^{\circ} \mathrm{C}$ and viscosity at $90^{\circ} \mathrm{C}$ for $20 \mathrm{~min}$ ) (Merca \& Juliano, 1981) was calculated. Results were expressed in Brabender Units (BU).

\subsection{Chemical composition}

The chemical composition was determined by triplicate, according to the official technical AOAC (Association of Official Analytical Chemists, 1996): moisture (method 934.01), protein (method 960.52), ash (method 942.05), lipid (method 920.39) and total dietary fibre (TDF) (method 991.43). The value of carbohydrates was calculated by difference.

\subsection{Sensory assay}

The evaluation and testing preferences were analysed in 60 consumers, men and women, over 18 years, using a hedonic scale of 7 points, where 1 corresponds to the statement "I dislike it very much" and 7 corresponds to "I like it very much." In addition, the consumers were asked to their intention to either purchase or consume product if they have the products at home.

\subsection{Statistical analysis}

Means and standard deviation (SD) were calculated. For data analysis the ANOVA analysis was used. For the comparison of means to establish significant differences $(\mathrm{p}<0.05)$, the Tukey test was used. Pearson correlation coefficients $\left(r^{2}\right)$ were used to determine the relationship between acceptability and other studied variables. The 2008 version InfoStat Statistical Software was used.

\section{Results and discussion}

\subsection{Bulk density (BD) and Expansion Index (EI)}

Table 1 shows the bulk density and Expansion Index of the studied samples. The density of grains indicates that the amount of air spaces was low (uniform and small). The grains that have higher density contain a larger amount of reserve substances (nutrients), this condition being the most desirable; however, in expanded products, since economically those with less bulk and real density are selected (Egas et al., 2010). Did not show a significant difference between CPA $(0.17 \mathrm{~g} / \mathrm{ml})$ and PK $(0.18 \mathrm{~g} / \mathrm{ml})$ ( $p>0.05)$ in the BD, but there was significant difference with the raw grain $(0.85 \mathrm{~g} / \mathrm{ml})$ and $\mathrm{LK}(0.38 \mathrm{~g} / \mathrm{ml})(\mathrm{p}<0.05)$. The EI 
is of great importance in evaluating the product quality, since it is possible to verify whether the raw material used after the processing possesses suitable structure and composition for use as a food ingredient (Silva et al., 2013). The degree of expansion of an extruded product is closely related to the size, number, and distribution of air cells surrounded by the cooked material (Salata et al., 2014). In the PK, the lower density $(0.18 \mathrm{~g} / \mathrm{ml})$ indicated that during the puffed process, an excellent expansion of the product (4.60). Similar values of the EI were reported by Valdez (1999). In this study, statistically significant difference was observed between PK and LK $(\mathrm{p}<0.05)$. In another research where were studied different puffed cereals, the bulk density values were reported between $0.13-0.16 \mathrm{~g} / \mathrm{ml}$ and the EI between 5.3-7.6. This cooking process caused a drastic decrease in the $\mathrm{BD}$ and an increase in the IE (Mariotti et al., 2006).

\subsection{Determination of colour. Yellow Index (YI)}

Table 1 shows the colorimetric parameters and Yellow Index of the studied samples. Colour is a very important quality attribute of both raw and processed foods. It has a significant impact on consumer perception of quality. Puffed cereal grains should be characterized by a bright and uniformly distributed colour, with high values of lightness and whiteness. Investigators confirmed that amaranth grain puffing process at higher temperatures may lead to scorching and stiffening of the natural grain cover (Zapotoczny et al., 2006). Also, many reactions occur during precooking process that can affect the colour such us Maillard reaction, where lysine and other amino acids present in the raw material probably react with reducing sugars, favoured by the processing conditions, which leads to a darkening of the extruded and expanded products (Gutkoski \& El-Dash, 1999). In the present study, the kiwicha grain had higher values of $L^{*}(60.96 \pm 0.18)$ and $b^{*}(28.01 \pm 0.98)$ than those reported by Kaur et al. (2010). But was obtained similar values of $\mathrm{a}^{\star}(13.86 \pm 0.79)$. These authors established a predominance of reddish brown. Other researchers have reported similar values of $\mathrm{L}^{*}$ and $\mathrm{b}^{*}$, with higher values of $\mathrm{a}^{*}$ (Zapotoczny et al., 2006). LK $(67.56 \pm 0.43)$ and CPA $(65.30 \pm 1.12)$ showed higher values of $\mathrm{L}^{\star}$, than the raw grain $(60.96 \pm 0.18)$ and $\mathrm{PK}(61.51 \pm 1.26)$, with significant differences $(p<0.05)$. The lowest value of $a^{*}$ was KL $(9.05 \pm 0.07)(p<0.05)$. There was a decrease in yellow colour $\left(\mathrm{b}^{\star}\right)$ in PK $(21.93 \pm 0.84)$ and LK $(21.70 \pm 2.31)$, respect to the raw grain $(28.01 \pm 0.98)(\mathrm{p}<0.05)$. CPA had higher value of $\mathrm{b}^{*}(40.57 \pm 2.49)$ than the raw grain, PK and LK with significant differences $(\mathrm{p}<0.05)$. This could be due to the possible addition of colouring substances in the manufacturing process. Another colour parameter correlated with the quality of puffed amaranth grains is the index of yellowness. The composition of the puffed grain should differ as little as possible from the composition of raw material. Total whiteness and yellowness indices may serve as measures of this difference. The increase in yellowness and the decrease in whiteness may be a result of changes in the composition of processed amaranth grains (Zapotoczny et al., 2006). Table 1 shows that the YI decreased during puffed $(50.92 \pm 0.92)$ and lamination $(45.87 \pm 4.61)$ process, respect to the raw grain $(65.64 \pm 2.25)(\mathrm{p}<0.05)$. Researchers came to the same conclusion, but these researchers used temperatures above $200^{\circ} \mathrm{C}$, so they got lower YI values than this study (Zapotoczny et al., 2006). CPA presented the highest values of YI $(58.54 \pm 2.90)$ respect to PK and LK $(\mathrm{p}<0.05)$.

\subsection{Functional properties: water absorption index (WAI), solubility (WSI) and swelling power (SP)}

WAI measures the amount of water absorbed by starch granules after swelling in excess water and it used as an index of gelatinization (Van den Einde et al., 2003). In the gelatinization, the starch granule swells then breaks and releases the amylose outside of the granule. Starch swelling is a property related to its amylopectin, amylose acting as a diluent and swelling inhibitor and as a direct result of the swelling of the grain, there is an increase in starch solubility (Karim et al., 2000). Table 2 shows that the processing of kiwicha grain (WAI: $2.33 \pm 0.08$; WSI:

Table 1. Colorimetric parameters, Yellow Index, Bulk Density and Expansion Index of the raw grain, CPA, PK and LK.

\begin{tabular}{cccrr}
\hline Parameter & Raw Grain & CPA & PK & LK \\
\hline L $^{*}$ & $60.96 \pm 0.18^{\mathrm{a}}$ & $65.30 \pm 1.12^{\mathrm{b}}$ & $61.51 \pm 1.26^{\mathrm{a}}$ & $67.56 \pm 0.43^{\mathrm{b}}$ \\
$\mathrm{a}^{*}$ & $13.86 \pm 0.79^{\mathrm{b}}$ & $11.31 \pm 0.38^{\mathrm{ab}}$ & $13.20 \pm 0.07^{\mathrm{b}}$ & $9.05 \pm 0.07^{\mathrm{a}}$ \\
$\mathrm{b}^{*}$ & $28.01 \pm 0.98^{\mathrm{b}}$ & $40.57 \pm 2.49^{\mathrm{c}}$ & $21.93 \pm 0.84^{\mathrm{a}}$ & $21.70 \pm 2.31^{\mathrm{a}}$ \\
Yellow Index & $65.64 \pm 2.25^{\mathrm{d}}$ & $58.54 \pm 2.90^{\mathrm{c}}$ & $50.92 \pm 0.92^{\mathrm{b}}$ & $45.87 \pm 4.61^{\mathrm{a}}$ \\
Bulk Density (g/ml) & $0.85 \pm 0.004^{\mathrm{c}}$ & $0.17 \pm 0.00^{\mathrm{a}}$ & $0.18 \pm 0.00^{\mathrm{a}}$ & $0.38 \pm 0.00^{\mathrm{b}}$ \\
Expansion Index & - & - & $4.60 \pm 0.00^{\mathrm{a}}$ & $3.25 \pm 0.00^{\mathrm{b}}$ \\
\hline
\end{tabular}

Means \pm standard deviation $(n=4)$. Different letters between columns are significantly different $(p<0.05)$. g: grams; ml: millilitres.

Table 2. Water Absorption, Solubility Index and Swelling Power of the raw grain, PK, LK and CPA.

\begin{tabular}{cccc}
\hline Sample & WAI (g. gel/g. sample d.b) & WSI (\% soluble solids d.b) & SP (g. solids/g. sample d.b) \\
\hline Raw Grain & $2.33 \pm 0.08^{\mathrm{a}}$ & $6.60 \pm 0.77^{\mathrm{a}}$ & $2.48 \pm 0.07^{\mathrm{a}}$ \\
PK & $5.25 \pm 0.40^{\mathrm{c}}$ & $9.38 \pm 0.60^{\mathrm{c}}$ & $5.79 \pm 0.54^{\mathrm{c}}$ \\
LK & $3.92 \pm 0.01^{\mathrm{b}}$ & $8.62 \pm 0.01^{\mathrm{b}}$ & $4.25 \pm 0.01^{\mathrm{b}}$ \\
CPA & $7.59 \pm 0.20^{\mathrm{d}}$ & $11.66 \pm 0.77^{\mathrm{d}}$ & $8.50 \pm 0.29^{\mathrm{d}}$ \\
\hline
\end{tabular}

Means \pm standard deviation $(n=4)$. Different letters between rows are significantly different ( $p<0.05)$. g: gram; d.b: dry basis; WAI: Water Absorption Index, WSI: Water Solubility Index; SP: Swelling Power. 
$6.60 \pm 0.77$, SP: $2.48 \pm 0.07$ ) increased the WAI (PK: $5.25 \pm 0.40$; LK: 3.92 \pm 0.01$)$, the WSI (PK: 9.38 \pm 0.60 ; LK: $8.62 \pm 0.01)$ and the SP (PK: 5.79 \pm 0.54 ; LK: 4.25 \pm 0.01 ), showing significant differences $(p<0.05)$. This is because the expansion induces significant changes in the structure and physical properties of starch with greater water retention capacity (Mariotti et al., 2006). The water absorption capacity of precooked cereals can be interpreted based on interactions starch-water-protein, which is attributed to the dispersion of starch in excess water, due to the degree of damage suffered by gelatinization and fragmentation during processing (e.g., molecular weight, reduction of amylose and amylopectin) (Markowski et al., 2006). These interactions affect the structure of the solid phase of the processed material (Zapotoczny et al., 2006). CPA presented higher values in all studied parameters (WAI: 7.59 \pm 0.20 ; WSI: $11.66 \pm 0.77$; SP: $8.50 \pm 0.29)$, than the other products $(\mathrm{p}<0.05)$, while the lowest value was in KL (WAI: $3.92 \pm 0.01$; WSI: $8.62 \pm 0.01$; SP: $4.25 \pm 0.01$ ). Barca et al. (2010) studied the absorption capacity of puffed amaranth and they obtained higher values than those obtained in this study. This could be because the grain amaranth has a high level of amylopectin, low values obtained from this index can be attributed to the almost total degradation suffered by the starch granules in both processes precooking (Menegassi et al., 2011). González et al. (2000) suggested that the endosperm amaranth is less resistant than other waxy cereal and proposed to the WSI as a direct indicator of the degree of cooking of extruded cereals. This index determines the amount of soluble polysaccharide released from the starch granules in excess of water and is often used as an indicator a related with the degree of breaking of the granular structure and molecular components degradation (Salata et al., 2014; Van den Einde et al., 2003). This solubilizes amylose molecules and increased solubility (Kong et al., 2009).

\subsection{Pasting properties}

Pasting properties obtained are shown in Table 3. The pasting properties reflect the changes in the viscosity of the samples during heating in excess of water under constant stirring conditions. During heating, the viscosity increased due to the swelling of the granules to several times their original size, due to the loss of crystalline order and absorption of water (Bao \& Bergman, 2004). This increase could be due to water holding capacity of the starch granules, with increasing

Table 3. Pasting properties of the raw grain, PK, LK and CPA.

\begin{tabular}{lcccc}
\hline \multicolumn{1}{c}{ Pasting properties (BU) } & Raw grain & PK & LK & CPA \\
\hline Peak Viscosity & 418 & 100 & 150 & 130 \\
Viscosity $90{ }^{\circ} \mathrm{C}$ & 400 & 100 & 140 & 130 \\
Viscosity at $90{ }^{\circ} \mathrm{C}$ for & 345 & 100 & 140 & 130 \\
20 minutes & & & & \\
Viscosity $50{ }^{\circ} \mathrm{C}$ & 362 & 118 & 180 & 150 \\
Viscosity at $50{ }^{\circ} \mathrm{C}$ for 20 & 362 & 118 & 190 & 155 \\
minutes & & & & \\
Breakdown viscosity & 73 & 0 & 10 & 0 \\
Setback viscosity & 17 & 18 & 40 & 20 \\
Pasting temperature $\left({ }^{\circ} \mathrm{C}\right)$ & 63 & 68 & 70 & 69 \\
\hline
\end{tabular}

BU: Brabender Units. temperature, cause rupture of intermolecular hydrogen bonds of amorphous regions, and progressive and irreversible water absorption. Variation in the ability to bind water may be due to differences in the proportion of amorphous or crystalline regions within the starch granule (Kong et al., 2009). The pasting temperature is an index of system (association) intragranular, higher temperature values, there is a greater degree of association between the macromolecules inside the starch granule (Singh et al., 2003). In this study pasting temperature for the raw grain of Kiwicha was $63^{\circ} \mathrm{C}$. Pasting temperatures of $63.4-74{ }^{\circ} \mathrm{C}$ have been reported for grain amaranth from previous studies (Kong et al., 2009; Lai, 2001). The pasting temperature is an index of system (association) intragranular. When the temperature values are higher, there is a greater degree of association between the macromolecules inside the starch granule (Singh et al., 2003). The raw grain presented a peak viscosity of $418 \mathrm{BU}$. This is because during heating, the swollen starch granules disintegrate more in the absence of amylose, therefore, a higher viscosity (Singh et al., 2007). Studies on starch from different sources showed that the amylose content and the distribution of chain length predominantly amylopectin can affect the pasting properties (Jane et al., 1999). Researchers revealed that the amaranth grain has a lower final viscosity as compared to peak viscosity, and a tendency to retrogradation, possibly due to the absence or presence of a negligible amount amylose. In earlier studies, this characteristic has been observed in starches from waxy corn (Kaur et al., 2010; Sandhu et al., 2007). In another study the difference in the pasting properties of the two grain amaranth species, reflected differences in the content and/or nature of amylose to amylopectin of the starch. They concluded that the amylose content is a key factor in the pasting properties in the amaranth grain (Kong et al., 2009). In fact, according to some authors (Kong et al., 2009; Liu et al., 2006) state that the amylose content directly affects the viscosity, with a higher content of amylose, the viscosity is higher. This trend can be explained by the fact that all these pasting properties are dependent on the rate and level of starch granules during disintegration. At the end of the heating period, it decreased the viscosity in the raw grain to $345 \mathrm{BU}$ and at the end of cooling increased to 362 $\mathrm{BU}$ and maintained to this same viscosity for 20 minutes at $50{ }^{\circ} \mathrm{C}$. The breakdown viscosity of the raw grain $(73 \mathrm{BU})$ was less than the final viscosity (362 BU). This indicates that the sample is shearing stable. This viscosity is considered a measure of the degree of disintegration of the granules and reveals the stability of the paste. Samples that recorded largest granule disintegration, appears to show a high degree of retrogradation. This is reflected in the values of setback. In this study, in the raw grain was obtained a lower value of setback (17 BU). Higher values were reported by other researchers which studied two types of grain Amaranth cruentus L. and L. hipochondriacus (Muyonga et al., 2014). According to other authors, the retrogradation of the amaranth starch is small compared to corn and wheat starches, by the low amount of amylose present amaranth grain (Choi et al., 2004; Wilhelm et al., 2002). In the $\mathrm{PK}, \mathrm{LK}$ and CPA, the precooking starch resulted in increased solubilisation in cold water, increasing the water retention 
power and facilitating swelling and gelatinization of the starch granules. The precooked products had a lower peak viscosity of $100 \mathrm{BU}, 130 \mathrm{BU}$ and $150 \mathrm{BU}$ for PK, LK and CPA, respectively, than the raw grain $(418 \mathrm{BU})$. This can be attributed to the pregelatinize due to heat treatment (Ilo et al., 1999; Rodríguez-Sandoval et al., 2007). The precooking process reduced the breakdown viscosity (PK: 0 BU; LK: $10 \mathrm{BU}$; CPA: $0 \mathrm{BU}$ ), increased the setback viscosity (PK: $18 \mathrm{BU}$; LK: $30 \mathrm{BU}$; $\mathrm{CPA}: 20 \mathrm{BU})$ and increased the pasting temperature $\left(\mathrm{PK}: 68^{\circ} \mathrm{C}\right.$; LK: $70{ }^{\circ} \mathrm{C}$; CPA: $69^{\circ} \mathrm{C}$ ). This parameter gives an indication of the minimum temperature required for cooking starch suspensions (Pongsawatmanit et al., 2002). A similar trend was reported when comparing pasting properties of different grain amaranth cultivars (Kong et al. 2009). This trend can be explained by the fact that all these attributes are dependent on the pace and level of starch granule disintegration. Samples which register more extensive granule disintegration seem also likely to exhibit a high extent of retrogradation reflected in the values for setback (Muyonga et al., 2014).

\subsection{Chemical composition}

Table 4 presents the content of nutrients in raw grain, $\mathrm{PK}$ and LK. These values are expressed in grams per 100 grams of sample in dry basis (g/100g sample d.b). The raw grain had $7.2 \mathrm{~g} / 100 \mathrm{~g}$ of moisture and high value of TDF $(37.61 \mathrm{~g} / 100 \mathrm{~g})$. This value was higher compared to that reported by other authors (Escudero et al., 2004; Marcílio et al., 2003; Menegassi et al., 2011). Also, the grain presented a higher content of insoluble fibre $(32 \mathrm{~g} / 100 \mathrm{~g})$ than the content found in other studies (Escudero et al., 2004; Marcílio et al., 2003). The optimal protein value $(14.59 \mathrm{~g} / 100 \mathrm{~g})$ was similar to those reported by the United States Department of Agriculture (2010) and other researchers (Bressani, 2003; Repo-Carrasco-Valencia et al., 2009; Zheleznov et al., 1997). The lipid content $(4.66 \mathrm{~g} / 100 \mathrm{~g})$ was lower than that reported by Repo-Carrasco-Valencia et al. (2009), but this may depend on the species and genotype, because some researchers established ranges between 1.9\% and 9.7\% (Berger et al., 2003). The precooking process caused some changes in the chemical composition of the kiwicha grain. On the puffed, the moisture content was reduced by $56 \%$, from

Table 4. Nutritional value (g/100g d.b) of the raw grain, PK and LK.

\begin{tabular}{lrrr}
\hline \multicolumn{1}{c}{ Nutrient } & \multicolumn{1}{c}{ Raw grain } & \multicolumn{1}{c}{ PK } & \multicolumn{1}{c}{ LK } \\
\hline Moisture & $7.20 \pm 0.10^{\mathrm{b}}$ & $3.13 \pm 0.08^{\mathrm{a}}$ & $7.57 \pm 0.10^{\mathrm{b}}$ \\
Carbohydrates & $40.51 \pm 0.80^{\mathrm{a}}$ & $61.23 \pm 0.83^{\mathrm{b}}$ & $64.32 \pm 0.90^{\mathrm{b}}$ \\
Proteins & $14.59 \pm 0.50^{\mathrm{a}}$ & $14.57 \pm 0.50^{\mathrm{a}}$ & $14.58 \pm 0.65^{\mathrm{a}}$ \\
Lipids & $4.66 \pm 0.46^{\mathrm{a}}$ & $4.67 \pm 0.25^{\mathrm{a}}$ & $4.60 \pm 0.15^{\mathrm{a}}$ \\
Total Dietary & $37.61 \pm 0.00^{\mathrm{c}}$ & $13.94 \pm 0.00^{\mathrm{a}}$ & $16.88 \pm 0.00^{\mathrm{b}}$ \\
Fibre & & & \\
Soluble & $5.61 \pm 0.00^{\mathrm{c}}$ & $1.55 \pm 0.00^{\mathrm{a}}$ & $2,17 \pm 0.00^{\mathrm{b}}$ \\
Insoluble & $32.00 \pm 0.00^{\mathrm{c}}$ & $12.39 \pm 0.00^{\mathrm{a}}$ & $14.71 \pm 0.00^{\mathrm{b}}$ \\
Ash & $2.63 \pm 0.02^{\mathrm{b}}$ & $2.65 \pm 0.02^{\mathrm{b}}$ & $2.56 \pm 0.04^{\mathrm{a}}$ \\
Calories (Kcal) & $262.34 \pm 0.90^{\mathrm{a}}$ & $345.23 \pm 0.85^{\mathrm{b}}$ & $357.00 \pm 0.93^{\mathrm{c}}$ \\
\hline
\end{tabular}

Means \pm standard deviation $(n=3)$. Different letters between columns are significantly different ( $p<0.05)$; g: gram; d.b: dry basis; Kcal: Kilocalories.
$7.20 \mathrm{~g} / 100 \mathrm{~g}$ to $3.13 \mathrm{~g} / 100 \mathrm{~g}$, due to the effect of expansion, the high pressure and temperature $\left(160^{\circ} \mathrm{C}\right)$ of the process, which occurs first toasting and then puffed (Egas et al., 2010). Also, in the laminates there was a decrease of more than $50 \%$. In addition, the heat treatment decreased by between $55-60 \%$ of the FDT content (PK: $13.94 \mathrm{~g} / 100 \mathrm{~g}$; LK: $16.88 \mathrm{~g} / 100 \mathrm{~g}$ ). This decrease showed significant differences $(\mathrm{p}<0.05)$, compared to the raw grain. This is because the fibre is located in the outer layers of the grain, which causes their loss. The carbohydrate content was concentrated at the expense of the other components decrease, of $40.51 \mathrm{~g} / 100 \mathrm{~g}$ (raw grain) to $64.32 \mathrm{~g} / 100 \mathrm{~g}$ and $61.23 \mathrm{~g} / 100 \mathrm{~g}$ for the laminated and puffed of kiwicha, respectively. The content of protein, TDF, both soluble and insoluble and ash were similar to content found in another study, which was evaluated the properties of expanded amaranth (Menegassi et al., 2011). In another study, researchers evaluated raw and puffed amaranth and observed significant differences $(p<0.05)$ between the two samples in the content of moisture, protein, fat, ash and carbohydrates (Barca et al., 2010). In this study, there were not significant differences $(\mathrm{p}>0.05)$ in the content of protein and fat between studied samples.

\subsection{Sensory assay}

Table 5 shows the mean of the acceptability and percentage of preferably of PK, LK and CPA. PK had the better acceptability (5.84 \pm 1.16$)$, corresponding to the scale like moderately. There were statistically significant differences $(\mathrm{p}<0.05)$ between $\mathrm{PK}$, LK and CPA. The lowest acceptability was CPA (3.94 1.23$)$. The highest percentage of preferably was PK (84.48\%). Only the $6.90 \%$ of consumers preferred the CPA.

Figure 1 shows the intention of purchase and consumption of the PK, LK and CPA. The greater acceptance of purchase (38.79\%) and consumption (43.96\%) was for the PK. The commercial product showed acceptance at purchase, $33.62 \%$ and consumptions $27.59 \%$ of the tasters. Regarding the laminated kiwicha, the $40.52 \%$ and the $36.21 \%$, not purchased and not consumed, respectively, due to having poor flavour and texture did not please the consumer. Pearson correlation coefficients $\left(\mathrm{r}^{2}\right)$ indicated that the acceptability assays is positively correlated $(\mathrm{p}<0.05)$ with: $\mathrm{BD}\left(\mathrm{r}^{2}=0.95\right), \mathrm{L}^{*}\left(\mathrm{r}^{2}=0.99\right), \mathrm{a}^{*}\left(\mathrm{r}^{2}=0.95\right)$, WAI $\left(r^{2}=0.93\right)$ and SP $\left(r^{2}=0.92\right)$ in CPA; WAI $\left(r^{2}=0.92\right)$, WSI $\left(\mathrm{r}^{2}=0.91\right), \mathrm{SP}\left(\mathrm{r}^{2}=0.92\right)$ and FDT $\left(\mathrm{r}^{2}=0.96\right)$ in PK; $\mathrm{L}^{*}\left(\mathrm{r}^{2}=0.99\right)$ in LK. There was a negative correlation with: $\mathrm{BD}\left(\mathrm{r}^{2}=-0.92\right)$, WSI $\left(r^{2}=-0.90\right)$, FDT $\left(r^{2}=-0.91\right)$ and carbohydrates $\left(r^{2}=-0.93\right)$ in LK; $b^{*}\left(r^{2}=-0.95\right)$ in CPA.

Table 5. Acceptability and percentage of preference of the PK, LK and CPA.

\begin{tabular}{lccc}
\hline \multicolumn{1}{c}{ Parameters } & PK & LK & CPA \\
\hline Acceptability & $5.84 \pm 1.16^{\mathrm{c}}$ & $4.20 \pm 1.40^{\mathrm{b}}$ & $3.94 \pm 1.23^{\mathrm{a}}$ \\
Preference (\%) & 84.48 & 8.62 & 6.90 \\
\hline
\end{tabular}

Acceptability: Means \pm standard deviation $(n=60)$. Different letters between columns are significantly different $(p<0.05)$. 


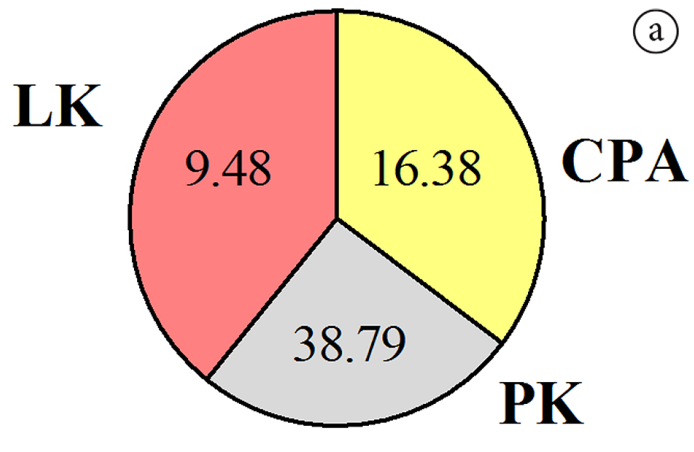

(b)

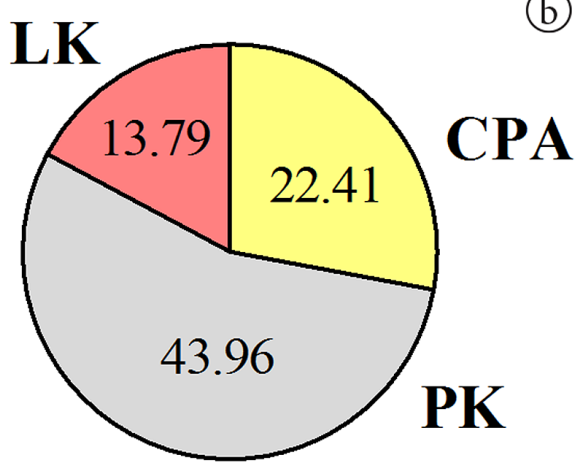

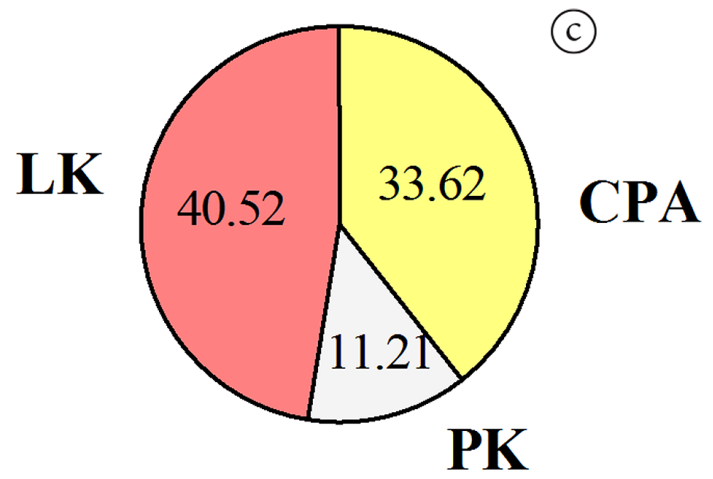

(d)

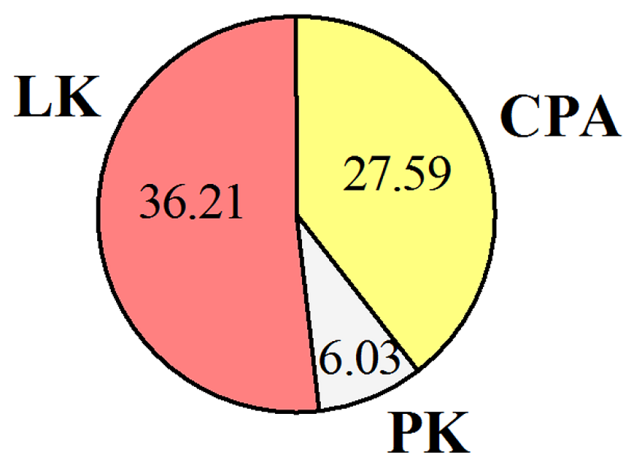

Figure 1. Intention of purchase and consumption (\%) of the PK, LK and CPA. a: Yes. Purchase; b: Yes Consumption; c: No. Purchase; d: No. Consumption.

\section{Conclutions}

Density determinations and rate of expansion provided good grain quality characteristics. In the formulated products, PK and LK, an excellent expansion was achieved. Colour and YI allowed predicting an important quality of the laminated and puffed product and their perception of the quality of the kiwicha grain. Precooked formulated products had high content of total, soluble and insoluble fibre. The precooking process in the kiwicha grain increased the WAI, WSI and SP, the setback viscosity and the pasting temperature. Also, these processes reduced the breakdown viscosity, indicating greater stability to heating and cooling processes, faster cooking and swell in cold. The PK presented better sensorial acceptability than CPA. The PK acceptability was correlated with the WAI, WSI, SP and the content of FDT. The LK to improve their sensory acceptability could be incorporated as an ingredient in other formulations, instant products such as soups, desserts, drinks. The commercial product should have better sensory characteristics to improve its acceptability, consumption and purchase. We conclude that from this research the precooked products obtained have good quality characteristics, physical and functional properties, chemical composition and acceptability. This allows its use for the development of new products for useful purposes, such as breakfast cereals or ingredients of other products with higher added value.

\section{Acknowledgements}

The authors wish to thank Professors Alejandra Burgos and Colin Bailey for their valuable help revising the language and we thank the director of the Research Institute of Sensory Food, Lic. Raquel Guanca, for providing the venue and materials to carry out tests of Sensory Evaluation. Also, we thank the Magister Juan Robin, for his cooperation in the use of the laminator and development the laminated kiwicha.

\section{References}

Anderson, R. A., Conway, H. F., Pfeifer, V. F., \& Griffin, E. L. (1969). Roll and extrusion cooking of grain sorghum grits. Cereal Science Today, 14, 372-376.

Association of Official Analytical Chemists - AOAC. (1996). Official methods of analysis (16th ed.). Washington.

Bao, J., \& Bergman, C. J. (2004). The functionality of rice starch. In A. C. Eliasson (Ed.), Starch in food (chap. 9, pp. 259-294). England: Woodhead Publishing.

Barca, A. M., Rojas-Martínez, M. E., Islas-Rubio, A. R., \& CabreraChávez, F. (2010). Gluten-free breads and cookies of raw and popped amaranth flours with attractive technological and nutritional qualities. Plant Foods for Human Nutrition, 65(3), 241-246. http:// dx.doi.org/10.1007/s11130-010-0187-z. PMid:20734143.

Berger, A., Gremaud, G., Baumgartner, M., Rein, D., Monnard, I., Kratky, E., Geiger, W., Burri, J., Dionisi, F., Allan, M., \& Lambelet, P. (2003). Cholesterol-lowering properties of amaranth grain and 
oil in hamsters. International Journal for Vitamin and Nutrition Research, 73(1), 39-47. http://dx.doi.org/10.1024/0300-9831.73.1.39. PMid:12690910.

Boischot, C., Moraru, C. I., \& Kokini, J. L. (2003). Factors that influence the microwave expansion of glassy amylopectin extrudates. Cereal Chemistry, 80(1), 56-61. http://dx.doi.org/10.1094/CCHEM.2003.80.1.56.

Bressani, R. (2003). Amaranth. In L. Trugo, P. M. Finglas, B. Caballero (Eds.), Encyclopedia of Food Sciences and Nutrition (pp. 166-173). England: Academic Press.

Bressani, R. (2006). Estudios sobre la industrialización del grano de amaranto: caracterización química y nutricional de productos intermedios y finales del procesamiento. Guatemala: Universidad del valle de Guatemala. Proyecto FODECYT N²3-2002. Retrieved from: http://glifos.concyt.gob.gt/digital/fodecyt/fodecyt\%202002.23.pdf

Chandrasekhar, P. R., \& Chattopadhyay, P. K. (1990). Studies on microstructural changes of parboiled and puffed rice. Journal of Food Science and Technology, 22, 115-118.

Chavez-Jauregui, R. N., Silva, M., \& Arêas, J. A. G. (2000). Extrusion cooking process for amaranth (Amaranthus caudatus L.). Journal of Food Science, 65(6), 1009-1015. http://dx.doi.org/10.1111/j.1365-2621.2000. tb09408.x.

Chen, C. H., \& Yeh, A. I. (2001). Effect of amylose content on expansion of extruded rice pellet. Cereal Chemistry, 78(3), 261-266. http:// dx.doi.org/10.1094/CCHEM.2001.78.3.261.

Choi, H., Kim, W., \& Shin, M. (2004). Properties of Korean amaranth starch compared to waxy millet and waxy sorghum starches. Stärke, 56(10), 469-477. http://dx.doi.org/10.1002/star.200300273.

Egas, L., Villacrés, E., Salazar, D., Peralta, E., \& Ruilova, M. (2010, May 24). Elaboración de un cereal para desayuno con base a quinua (Chenopodium quinoa Willd) expandida. Revista Tecnológica ESPOL-RTE, 23(2), 9-15. Retrieved from: www.rte.espol.edu.ec/ index.php/tecnologica/article/download/50/21

Escudero, N. L., de Arellano, M. L., Luco, J. M., Giménez, M. S., \& Mucciarelli, S. I. (2004). Comparison of the chemical composition and nutritional value of Amaranthus cruentus flour and its protein concentrate. Plant Foods for Human Nutrition, 59(1), 15-21. http:// dx.doi.org/10.1007/s11130-004-0033-3. PMid:15675147.

Gamel, T. H., Linssen, J. P., Mesallam, A. S., Damir, A. A., \& Shekib, L. A. (2006). Seed treatments affect functional and antinutritional properties of amaranth flours. Journal of the Science of Food and Agriculture, 86(7), 1095-1102. http://dx.doi.org/10.1002/jsfa.2463.

Gamel, T. H., Mesallam, A. S., Damir, A. A., Shekib, L. A., \& Linssen, J. P. (2007). Characterization of amaranth seeds oils. Journal of Food Lipids, 14(3), 323-334. http://dx.doi.org/10.1111/j.1745-4522.2007.00089.x.

Gavrielidou, M., Vallous, N. A., Karapantsios, T. D., \& Raphaelideset, S. N. (2002). Heat transport to starch slurry gelatinizing between the drums of a double drum dyer. Journal of Food Engineering, 54(1), 45-58. http://dx.doi.org/10.1016/S0260-8774(01)00184-4.

Gökmen, S. (2004). Effects of moisture content and popping method on popping characteristics of popcorn. Journal of Food Engineering, 65(3), 357-362. http://dx.doi.org/10.1016/j.jfoodeng.2004.01.034.

González, R. J., Torres, R. L., \& Añón, M. C. (2000). Comparison of rice and corn cooking characteristics before and after extrusion. Polish Journal of Food and Nutrition Sciences, 9(1), 29-34.

Gutkoski, L. C., \& El-Dash, A. A. (1999). Effect of extrusion process variables on physical and chemical properties of extruded oat products. Plant Foods for Human Nutrition, 54(4), 315-325. http:// dx.doi.org/10.1023/A:1008101209353. PMid:10798342.
Ilo, S., Liu, Y., \& Berghofer, E. (1999). Extrusion cooking of rice flour and amaranth blends. Food Science and Technology, 32(2), 79-88. http://dx.doi.org/10.1006/fstl.1998.0497.

Jane, J., Chen, Y. Y., Lee, L. F., McPherson, A. E., Wong, K. S., Radosavljevic, M., \& Kasemsuwan, T. (1999). Effects of amylopectin branch chain length and amylose content on the gelatinization and pasting properties of starch. Cereal Chemistry, 76(5), 629-637. http://dx.doi. org/10.1094/CCHEM.1999.76.5.629.

Karim, A. A., Norziah, M. H., \& Seow, C. C. (2000). Methods for the study of starch retrogradation. Food Chemistry, 71(1), 9-36. http:// dx.doi.org/10.1016/S0308-8146(00)00130-8.

Kaur, S., Singh, N., \& Rana, J. C. (2010). Amaranthus hypochondriacus and Amaranthus caudatus germplasm: Characteristics of plants, grain and flours. Food Chemistry, 123(4), 1227-1234. http://dx.doi. org/10.1016/j.foodchem.2010.05.091.

Kong, X., Bao, J., \& Corke, H. (2009). Phisycal properties of Amaranthus starch. Food Chemistry, 113(2), 371-376. http://dx.doi.org/10.1016/j. foodchem.2008.06.028.

Lai, H. (2001). Effects of hydrothermal treatment on the physicochemical properties of pregelatinized rice flour. Food Chemistry, 72(4), 455463. http://dx.doi.org/10.1016/S0308-8146(00)00261-2.

Liu, H., Yu, L., Xie, F., \& Chen, L. (2006). Gelatinization of corn starch with different amylose/amylopectin content. Carbohydrate Polymers, 65(3), 357-363. http://dx.doi.org/10.1016/j.carbpol.2006.01.026.

López-Mejía, O. A., López-Malo, A., \& Palou, E. (2014). Antioxidant capacity of extracts from amaranth (Amaranthus hypochondriacus L.) seeds or leaves. Industrial Crops and Products, 53, 55-59. http:// dx.doi.org/10.1016/j.indcrop.2013.12.017.

Marcílio, R., Amaya-Farfan, J., Ciacco, C. F., \& Spehar, C. F. (2003). Fracionamento do grão de amaranto (A. cruentus) brasileiro e suas características composicionais. Ciencia e Tecnologia de Alimentos, 23(3), 511-516. http://dx.doi.org/10.1590/S0101-20612003000300035.

Mariotti, M., Alamprese, C., Pagani, M. A., \& Lucisano, M. (2006). Effect of puffing on ultrastructure and physical characteristics of cereal grains and flours. Journal of Cereal Science, 43(1), 47-56. http://dx.doi.org/10.1016/j.jcs.2005.06.007.

Markowski, M., Ratajski, A., Konopko, H., Zapotoczny, P., \& Majewska, K. (2006). Rheological behavior of hot-air-puffed amaranth seeds. International Journal Food Properties, 9(2), 195-203. http://dx.doi. org/10.1080/10942910600596076.

Menegassi, B., Pilosof, A. M. R., \& Arêas, J. A. G. (2011). Comparison of properties of native and extruded amaranth (Amaranthus cruentus L. e BRS Alegria) flour. Food Science and Technology, 44(9), 1915-1921..

Merca, F. E., \& Juliano, B. O. (1981). Physicochemical properties of starch of intermediate-amylosa and waxy rice differing in grain quality. Stärke, 33(8), 253-260. http://dx.doi.org/10.1002/star.19810330802.

Milán-Carrillo, J., Montoya-Rodríguez, A., \& Reyes-Moreno, C. (2012). High-antioxidant capacity beverages based on extruded and roasted amaranth (Amaranthus hypochondriacus) flour. In M. H. Tunick \& E. González de Mejías (Eds.), Hispanic foods: chemistry and bioactive compounds (chap. 13, pp. 199-216). Washington: American Chemical Society.

Montoya-Rodríguez, A., Gómez-Favela, M. A., Reyes-Moreno, C., MilánCarrillo, J., \& González de Mejía, E. (2015). Identification of bioactive peptide sequences from amaranth (Amaranthus hypochondriacus) seed proteins and their potential role in the prevention of chronic diseases. Comprehensive Reviews in Food Science and Food Safety, 14(2), 139-158. http://dx.doi.org/10.1111/1541-4337.12125.

Moraru, C. I., \& Kokini, J. L. (2003). Nucleation and expansion during extrusion and microwave heating of cereal foods. Comprehensive 
Reviews in Food Science and Food Safety, 2(4), 147-165. http://dx.doi. org/10.1111/j.1541-4337.2003.tb00020.x.

Muyonga, J. H., Andabati, B., \& Ssepuuya, G. (2014). Effect of heat processing on selected grain amaranth physicochemical properties. Food Science \& Nutrition, 2(1), 9-16. http://dx.doi.org/10.1002/ fsn3.75. PMid:24804060.

Palombini, S. V., Claus, T., Maruyama, S. A., Gohara, A. K., Pereira Souza, A. H., Souza, N. E., Visentainer, J. V., Marques Gomes, S. T., \& Matsushita, M. (2013). Evaluation of nutritional compounds in new amaranth and quinoa cultivars. Food Science and Technology, 33(2), 339-344. http://dx.doi.org/10.1590/S0101-20612013005000051.

Pongsawatmanit, R., Thanasukarn, P. Y., \& Ikeda, S. (2002). Effect of sucrose on RVA viscosity parameters, water activity and freezable water fraction of cassava starch suspensions. Science Asia, 28(2), 129134. http://dx.doi.org/10.2306/scienceasia1513-1874.2002.28.129.

Repo-Carrasco-Valencia, R., Peña, J., Callio, H., \& Salminen, S. (2009). Dietary fiber and other functional components of two varieties of crude and extruded Kiwicha (Amaranthus caudatus). Journal of Cereal Science, 49(2), 219-224. http://dx.doi.org/10.1016/j.jcs.2008.10.003.

Rodríguez-Sandoval, E., Sandoval-Aldana, A., \& Fernández-Quintero, A. (2007, April 2). Evaluación de la retrogradación del almidón en harina de yuca precocida. Revista Colombiana de Química, 36(1), 13-30. Retrieved from: http://www.redalyc.org/articulo. oa? id=309026671002

Rufian Henares, J. A., Guerra-Hernandez, E., \& Garcia-Villanova, B. (2006). Colour measurement as indicator for controlling the manufacture and storage of enteral formulas. Food Control, 17(6), 489-493. http://dx.doi.org/10.1016/j.foodcont.2005.02.011.

Salata, C., Leonel, M., Trombini, F. R. M, \& Mischan, M. M. (2014). Extrusion of blends of Cassava Leaves and Cassava Flour: physical characteristics of extrudates. Food Science and Technology, 34(3), 501-506. http://dx.doi.org/10.1590/1678-457x.6337.

Sandhu, K. S., Singh, N., \& Lim, S. T. (2007). Functional properties of normal, waxy and sugary corn starches. Journal of Food Science and Technology, 44, 565-571.

Sathe, S. K., \& Salunkhe, D. K. (1981). Isolation partial characterization and modification of the Great North bean (Phaseolus vulgaris) starch. Journal of Food Science, 46(4), 617-621. http://dx.doi. org/10.1111/j.1365-2621.1981.tb04924.x.

Schoch, J. T. (1964). Swelling power and solubility of granular starches. In L. R. Whistler, J. R. Smith \& N. J. BeMiller (Eds.), Methods in carbohydrate chemistry (chap. 4, pp. 42-46). New York: Academic Press.
Schoenlechner, R., Siebenhandl, S., \& Berghofer, E. (2008). Pseudocereals. In E. K. Arendt \& F. Dal Bello (Eds.), Gluten-Free cereal products and beverages (chap. 6, pp. 149-190). London: Academic Press.

Shimoni, E., Dirks, E. M., \& Labuza, T. P. (2002). The relation between final popped volume of popcorn and thermal-physical parameters. Lebensmittel-Wissenschaft und-Technologie, 35(1), 93-98.

Silva, R., Alvarenga Pereira, R. G. F., Ramirez Ascheri, J. L., \& Ramirez Ascheri, D. P. (2013). Technological properties of precooked flour containing coffee powder and rice by thermoplastic extrusion. Food Science and Technology, 33(1), 7-13. http://dx.doi.org/10.1590/ S0101-20612013005000014.

Singh, N., Nakaura, Y., Inouchi, N., \& Nishinari, K. (2007). Fine structure, thermal and viscoelastic properties of starches separated from India rice cultivars. Starch, 59(1), 10-20. http://dx.doi.org/10.1002/ star.200600527.

Singh, N., Singh, J., Kaur, L., Singh, S. N., \& Singh, G. B. (2003). Morphological, thermal and rheological properties of starches from different botanical sources. Food Chemistry, 81(2), 219-231. http:// dx.doi.org/10.1016/S0308-8146(02)00416-8.

United States Department of Agriculture - USDA. (2010, May 10). Nutrient Data Laboratory. Retrieved from: http://www.nal.usda. gov/fnic/foodcomp/cgi-bin/measure.pl

Valdez, N. V. L. (1999). Estudio del efecto de la expansión por aire caliente en las propiedades fisicoquímicas, nutricionales y sensoriales de la semilla de Amaranto (Amaranthus caudatus) (Master's thesis). Escuela Politécnica Nacional, Instituto de Investigación Tecnológica, Quito-Ecuador.

Van den Einde, R. M., Van der Goot, A. J., \& Boom, R. M. (2003). Understanding molecular weight reduction of starch during heatingshearing process. Journal of Food Science, 68(8), 2396-2404. http:// dx.doi.org/10.1111/j.1365-2621.2003.tb07036.x.

Wilhelm, E., Aberle, T., Burchard, W., \& Landers, R. (2002). Peculiarities of aqueous amaranth starch suspensions. Biomacromolecules, 3(1), 17-26. http://dx.doi.org/10.1021/bm000138+. PMid:11790134.

Zapotoczny, P., Markowski, M., Majewska, K., Ratajski, A., \& Konopko, H. (2006). Effect of temperature on the physical, functional, and mechanical characteristics of hot-air-puffed amaranth seeds. Journal of Food Engineering, 76(4), 469-476. http://dx.doi.org/10.1016/j. jfoodeng.2005.05.045.

Zheleznov, A. V., Solonenko, L. P., \& Zheleznova, N. B. (1997). Seed protein of the wild and the cultivated Amaranthus species. Euphytica, 97(2), 177-182. http://dx.doi.org/10.1023/A:1003073804203. 